\title{
Introduksi Indukan dan Alih Teknologi Pembenihan Lobster Air Tawar (Cerax quadricarinatus) pada Kelompok Masyarakat di Kecamatan Ladongi Kabupaten Konawe Timur
}

\section{Broodstock Introduction and Technology Transfer of Crayfish (Cerax quadricarinatus) Hatchery in the Community Groups in Ladongi Subdistrict, East Konawe Regency}

\author{
${ }^{1}$ Yusnaini, ${ }^{2}$ M. Ramli, ${ }^{3}$ Zainuddin Saenon, ${ }^{1}$ Indriyani Nur, ${ }^{4}$ Indrayani, \\ ${ }^{1}$ Program Studi Budidaya Perairan, Fakultas Perikanan dan Ilmu Kelautan, Universitas \\ Halu Oleo, Kendari \\ ${ }^{2}$ Program Studi Ilmu Kelautan, Fakultas Perikanan dan Ilmu Kelautan, Universitas Halu \\ Oleo, Kendari \\ ${ }^{3}$ Program Studi Ekonomi, Fakultas Ekonomi dan Bisnis, Universitas Halu Oleo, Kendari \\ 4Program Studi Manajemen Sumberdaya Perairan, Fakultas Perikanan dan Ilmu \\ Kelautan, Universitas Halu Oleo, Kendari
}

Korespondensi: Yusnaini, yusnaini@uho.ac.id

Naskah Diterima: 18 Desember 2019. Disetujui: 11 Juni 2020. Disetujui Publikasi: 23 Juni 2020

\begin{abstract}
Crayfish is an introduced species that has the potential to be developed. However, Its development is hindered by the availability of the seeds. The aim of this activity was to transfer crayfish hatchery technology into two community groups in Ladongi Subdistrict, East Konawe Regency. These activities were conducted from 2017-2018. The forms of activities were hatchery extension/training, introduction of crayfish broodstocks, contruction of breeding ponds and hatcheries and evaluation of knowledge, skills, availability of production facilities and the ability of partners to produce caryfish seeds. The results showed that the knowledge level of participants based on indicators was $55-91 \%$, from know nothing to know many things about crayfish. The skill level of participants based on indicators was $64-100 \%$, from unable to be able to seed crayfish. Both groups are able to manage resources and produce seeds, and as crayfish suppliers. In addition to seed production, the groups also produce crayfish for consumption and for broodstocks.
\end{abstract}

Keywords: Crayfish, hatcheries, technology transfer, community groups.

\begin{abstract}
Abstrak. Lobster air tawar (LAT) merupakan spesies introduksi yang potensi dikembangkan, namun terkedala pada ketersediaan benih.Kegiatan ini bertujuan mentransfer teknologi pembenihan LAT kepada dua kelompok masyarakat di Kecamatan Ladongi Kabupaten Kolaka Timur. Kegiatan direalisasikan tahun 2017-2018. Bentuk kegiatan yaitu penyuluhan/pelatihan pembenihan, introduksi indukan LAT, konstruksi kolam indukan dan pembenihan. Evalusi tingkat pengetahuan, keterampilan, ketersediaan sarana produki dan kemampuan mitra memproduksi benih LAT. Hasil kegiatan menunjukan bahwa, tingkat serapan pengetahuan peserta berdasarkan indikator yaitu 5591\%, dari tidak tahu menjadi tahu tentang LAT. Tingkat keterampilan peserta berdasarkan indikator 64-100\%, dari tidak bisa menjadi bisa membenihkan LAT. Kedua kelompok
\end{abstract}


mampu mengelola sumberdaya dan memproduksi benih, sebagai penyuplaiLAT. Selain bentuk benih kelompok memproduksi LAT ukuran konsumsi dan indukan bertelur.

Kata Kunci: Lobster air tawar, pembenihan, alih teknologi, kelompok masyarakat

\section{Pendahuluan}

Lobster air tawar (LAT) jenis Cherax quadicarinatus, red claw atau lobster capit merah merupakan komoditas yang diintroduksi dari Australia (Patoka et al. 2018) yang mempunyai keunggulan dari segi biologis, mudah bereproduksi dan beradaptasi, dan secara teknis mudah dibudidayakan dengan harga yang relatif tinggi/mahal.

Budidaya LAT merupakan alternatif untuk memenuhi kebutuhan sebagai makanan, jaminan keberlanjutan produksi dibutuhkan benih yang dapat disuplai dari pembenihan LAT (Ghanawil \& Saoud, 2012). Sistem pembenihan LAT dapat dilakukan secara intensif (Parnes \& Sagi 2002). Komoditas tersebut dapat dibenihkan dan mudah dibudidayakan, tidak mudah terserang penyakit, bersifat omnivora, tidak membutuhkan suhu terlalu dingin, dapat tumbuh sampai ukuran panjang badan $35 \mathrm{~cm} 500$ gram, dapat mencapai ukuran komsumsi (> 90 gr/ekor) dalam waktu 6 bulan pemeliharaan (Yusnaini, 2004)

Kabupaten Kolaka Timur, merupakan satu-satunya kabupaten/kota di Provinsi Sulawesi Tenggara yang tidak memiliki laut, tetapi mempunyai sumber daya perairan air tawar cukup luas, rawa 2.815 ha, persawahan $11.700,25$ ha, kolam pekarangan baruh terolah \pm 81 ha, masih ada ratusan hektar lahan potensi dikembangkan (Anonim, 2015), didukung sumberdaya air yang cukup tersedia, sarana bendungan dan irigasi Ladongi (Anonim, 2015, Yusnaini et al, 2018), namun budidaya LAT belum berkembang karena belum tersedia benih loster air tawar. Hal ini peluang untuk dikembangkan oleh kelompok-kelompok pembenihan ikan, dapat benjadi penyuplai kebutuhan benih LAT.

Kelompok pembudidaya atau pembenihan di Kecamatan Ladongi dan sekitarnya belum ada yang mengembangkan komoditas LAT, umumnya memelihara ikan mas, ikan nila, dan ikan lele. Mereka mempunyai motivasi yang tinggi untuk mengembangkan komoditas baru seperti LAT (Yusnaini et al, 2017). Kelompok masyarakat belum mengelola LAT sebagai komoditas usaha terkedala pada terbatasnya pengetahuan, belum mengetahui teknis pembenihan, tidak mempunyai indukan untuk dipijahkan, dan sarana pembenihan belum memadai untuk membenihkan LAT. Tranfer teknologi dapat berhasil jika dilakukan dengan pelatihan dan atau demontrasi plot pada masyarakat (Kudsiah et al, 2018)

Tujuan kegiatan ini yaitu melakukan penyuluhan, pelatihan atau bimbingan teknis pembenihan LAT, mengintroduksi indukan, menerapkan teknologi pembenihan, mengkontruksi sarana pembenihan. Manfaat kegiatan ini ada meningkatkan pengetahuan masyarakat tentang pembenihan LAT serta menyediakan sarana produksi pembenihan LAT pada kelompok msayarakat. Pada akhir kegiatan terbentuk kelompok masyarakat yang mempunyai pengetahuan, keterampilan, sarana pembenihan dan mampu memproduksi benih lobster air tawar.

\section{Metode Pelaksanaan}

Tempat dan Waktu, Kegiatan dilaksanakan di Desa Wulele Kecamatan Ladongi Kabupaten Kolaka Timur. Waktu pelaksanaan pada tahun 2017 dan dilanjutkan pendampingan dan monitoring pasca kegiatan pada tahun 2018.

Khalayak Sasaran. Khalayak sasaran adalah masyarakat yang mempunyai kolam ikan, melakukan budidaya ikan dan masyarakat lain yang tertarik membudidayakan LAT. Berdasarkan sistem pembenihan LAT yang diterapkan, kelompok mitra ada dua, yaitu sistem pembenihan di bak beton dan sistem pembenihan di kolam tanah, setiap kelompok beranggotakan 6 dan 5 orang. 
Metode Pengabdian. Kegiatan terdiri dari rangkaian proses :

1) penyululuhan/pelatihan: dilakukan dalam bentuk ceramah, diskusi, demonstrasi, praktek langsung.

2) konstruksi sarana pembenihan: dilakukan dengan membangun sarana produksi berupa bak-bak beton, yang dilengkapi dengan sarana aerasi dan sirkulasi air.

3) introduksi indukan LAT: indukan berupa indukan jantan dan betina yang diitroduksi dari luar ke lokasi untuk selanjutnya dipijahkan

4) proses produksi benih: indukan dipelihara bak-bak beton dan kolam secara berpasangan sambil menunggu sampai memijah, induk yang bertelur dipisahakan untuk sampai menetaskan telur dan menghasilkan benih.

5) pendampingan pembenihan: kontrol dilakukan secara periodik, konsultasi sampai masyarat atau mitra dapat memproduksi benih LAT.

Indikator Keberhasilan. Keberhasilan berdasarkan kelompok indicator yaitu :

1. Pengetahuan: Peserta mengetahui ciri utama LAT, dapat membedakan jenis kelamin, indukan yang layak dipijahkan dan kebutuhan dasar pembenihan LAT.

2. Keterampilan: Peserta dapat mengelompokkan indukan untuk dipijahkan, mampu menangkap indukan dengan baik tanpa menggunakan sarung tangan, memberi pakan, memeliharan indukan yang bertelur, melakukan penyapihan atau pemisahan benih dari induknya, memberi pakan pada benih,

3. Produksi dan kebelanjutan pembenihan: 2 kelompok memanfaatkan sarana yang diintroduksi secara kontinyu memproduksi benih dan penyuplai LAT di Kabupaten Kolaka Timur.

Metode Evaluasi. Evaluasi materi penyuluhan dilakukan sebelum dan setelah kegiatan. Dilakukan dalam bentuk tanya jawab tentang pembenihan pada kedua kelompok yang jumlah pesertanya 11 orang. Evaluasi keterampilan dengan metode aktif, peserta langsung mempraktekkan proses pembenihan dan kontinyuitas produksi benih. Hasil asesmen selanjutnya ditabulasi dan dianalisis secara kuantitatif dan deskriptif.

\section{Hasil dan Pembahasan}

\section{A. Pelaksanaan penyuluhan dan pelatihan}

Berdasarkan jenis pekerjaan, peserta terdiri dari pembudidaya ikan, pembenih ikan, petani sawah, petani kebun, pensiunan dan pegawai negeri sipil. Peserta tertarik atau berminat untuk mengetahui dan mengembangkan budidaya khususnya pembenihan LAT.

Materi pelatihan/bimbingan teknis yang dipaparkan adalah: Teknik pemilihan lokasi pembenihan LAT; Konstruksi kolam dan penataan aerasi dan pompa air untuk kolam indukan dan benih; Teknik pemeliharaan indukan, benih yang baru disapih; Teknik produksi indukan bertelur; Teknik pemberian pakan dan control kualitas air (Gambar 1)

Penyampaian materi diselingi dengan kegiatan aktif pengenalan LAT. Peserta menangkap indukan, memegang langsung LAT, mengamati perbedaan jenis kelamin indukan jantan atau betina, memilah indukan jantan dan betina, menilai ciri indukan LAT yang layak untuk dipijahkan.

Materi yang disampaikan dapat disimak oleh peserta dengan baik. Hasil evaluasi penguasaan materi menunjukkan bahwa, tingkat serapan pengetahuan peserta berdasarkan indikator yaitu $55-91 \%$, dari tidak tahu menjadi tahu tentang LAT. Secara akumulatif disajikan pada Gambar 2. Pengetahuan peserta tentang LAT meningkat, namun tingkat pemahamannya beragam, diduga disebabkan oleh latar belakang pekerjaan dan aktivitas keseharian peserta. Peserta yang memiliki kegiatan pembenihan ikan cepat menerima dan memahami materi penyuluhan jika 
dibandingkan dengan peserta lainnya yang berprofesi sebagai petani kebun. Secara umum, penyuluhan mampu meningkatkan pengetahuan dan motivasi peserta untuk mengembangkan budidaya LAT.

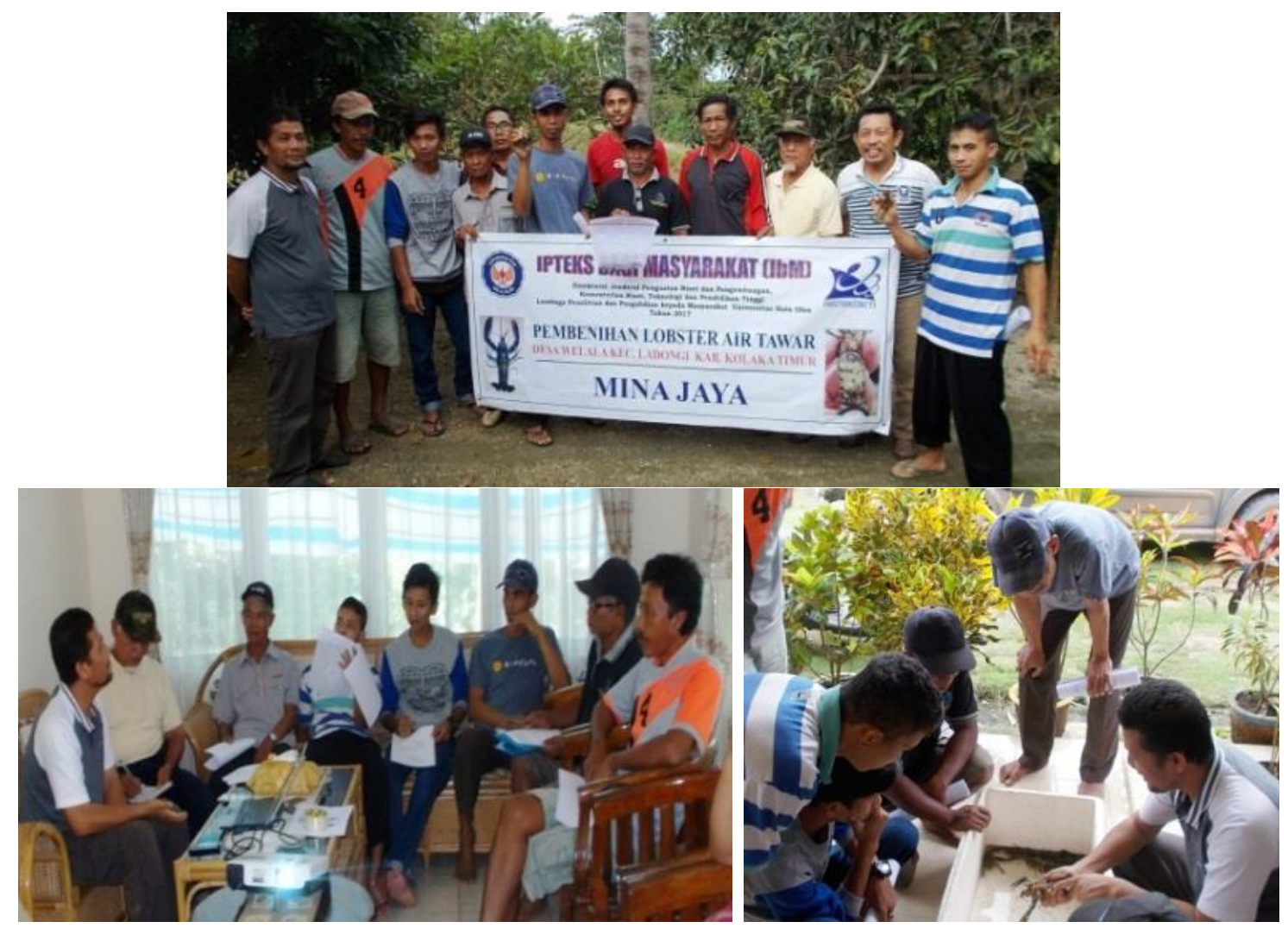

Gambar1. Suasana penyuluhan dan pelatihan pembenihan lobster air tawar

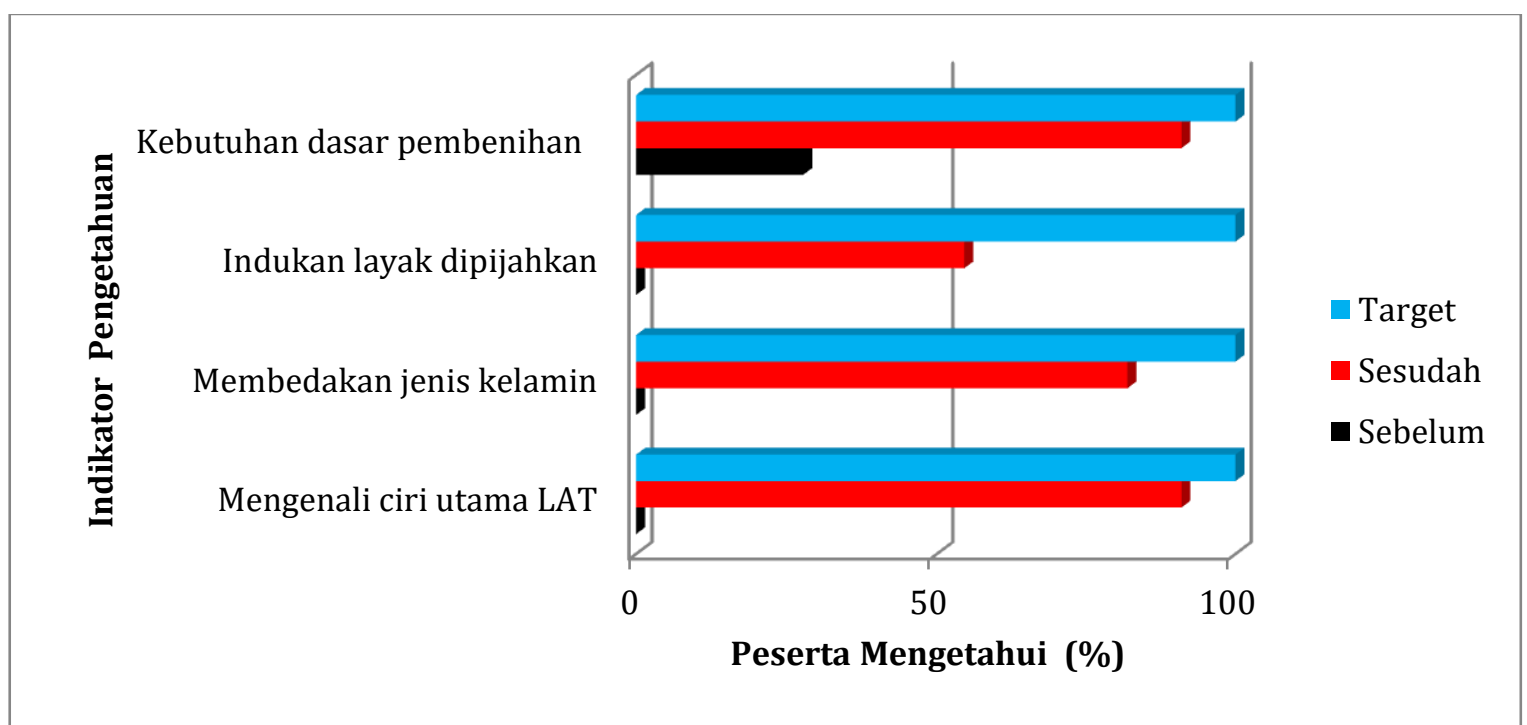

Gambar 2. Capaian pengetahuan peserta tentang lobster air tawar $(n=11)$

\section{B. Konstruksi Sarana Pembenihan}

Pada kegiatan ini, sarana produksi pendukung yang diberikan kepada kedua mitra, antara lain: instalasi suplai oksigen yang terdiri dari blower (pompa udara), batu aerasi, selang, kerang udara; Instalasi air yang terdiri dari pompa air dan pipa; Media pemeliharaan berupa bak-bak beton untuk pemeliharaan indukan dan 
benih. Sedangkan bangunan berupa rumah pembenihan dibangun dan ditanggung sendiri oleh mitra (Gambar 3).

Kolam yang dimiliki mitra direhabilitasi atau dikonstruksi ulang untuk kolam pemeliharaan indukan, indukan bertelur, dan kolam pemeliharaan benih dilaksanakan masing-masing kelompok. Indukan lobster air tawar (induk jantan dan betina) didatangkan dari penyuplai induk yang berkualitas. Indukan tersebut dibawa ke lokasi mitra. Indukan lobster yang diberikan kepada kedua mitra berukuran 100-150 g/ekor. Penyerahan indukan dilakukan 3 tahap, jumlahnya sebanyak 45 ekor atau 5 set (1 set terdiri dari 3 betina dan 2 jantan). Sarana produksi tersebut merupakan modal utama yang memadai bagi setiap kelompok untuk mengembangakn pembenihan LAT (Gambar 4).
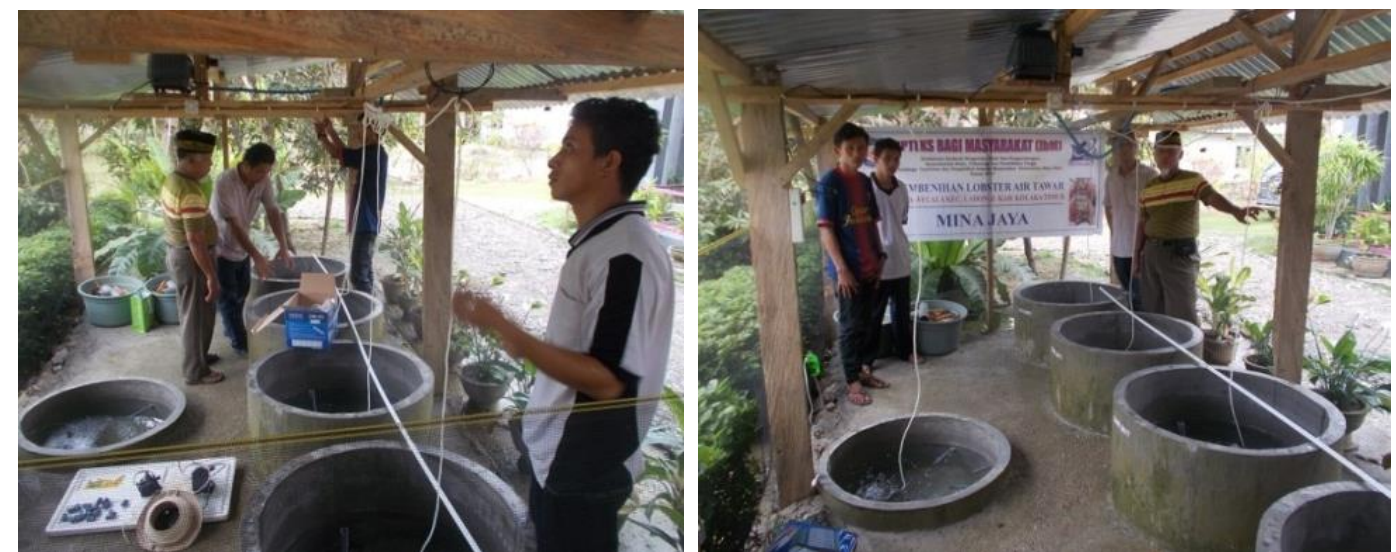

Gambar 3. Unit pembenihan lobster air tawar yang dikelola oleh mitra
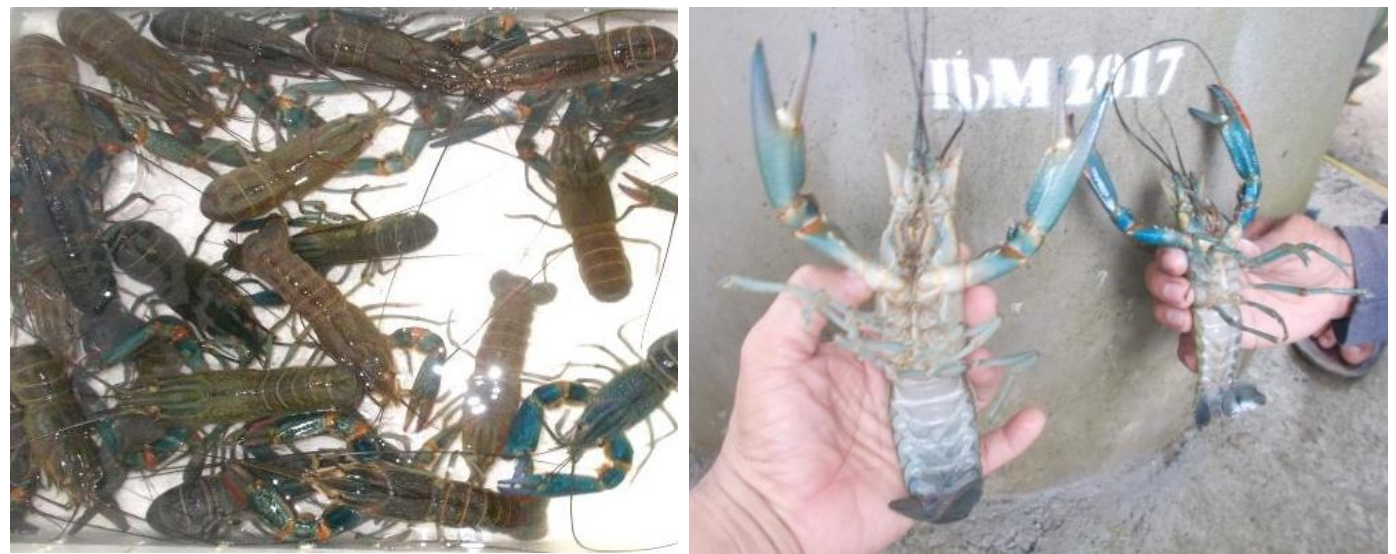

Gambar 4. Introduksi indukan lobster air tawar Cerax quadricarinatus

\section{Introduksi Indukan}

Setelah pelatihan, konstuksi sarana produksi seperti kolam pemeliharaan, adaptasi indukan, penyediaan pakan, maka dilanjutkan proses pembenihan. Setiap bak diisi berpasangan (jantan dan betina) atau satu set indukan ( 3 betina dan 2 jantan).

\section{Proses Produksi Benih}

Dalam waktu 14 hari pemeliharaan, mulai ada indukan yang memijah, ditandai dengan adanya telur menempel pada bagian abdomen induk betina. Indukan yang bertelur selanjutnya dipisahkan, dipelihara tersendiri dalam satu kolam atau bak air yang dilengkapi dengan aerasi dan sirkulasi air.

Telur berkembang dan menetas, namun larva masih menempel pada induknya. Setelah berumur 2-3 pekan, benih disapih dari induknya dan dilakukan 
pemeliharaan benih. Dalam waktu 2 bulan, kedua kelompok mitra telah berhasil memproduksi benih/anakan lobster air tawar yang siap dibesarkan atau dijual (Gambar 5 dan 6).

Hasil evaluasi keterampilan peserta dalam melakukan proses pembenihan LAT menunjukkan peningkatan yang tinggi. Tingkat keterampilan peserta berdasarkan indikator 64-100 \%, dari tidak bisa atau belum terampil menjadi bisa melakukan kegiatan pembenihan LAT. Hasil evaluasi keterampilan peserta, secara akumulatif disajikan pada Gambar 7. Tingkat keterampilan peserta belum merata, namun secara kelompok kedua kelompok telah berhasil menghasilkan benih lobster air tawar.

Benih LAT yang diproduksi umumnya dipelihara sendiri untuk dibesarkan sampai ukuran konsumsi atau sebagai indukan dan sebagian dijual pada ukuran benih. Setelah memasuki tahun kedua, mitra dapat memproduksi LAT dalam bentuk benih, ukuran konsumsi bahkan indukan LAT.

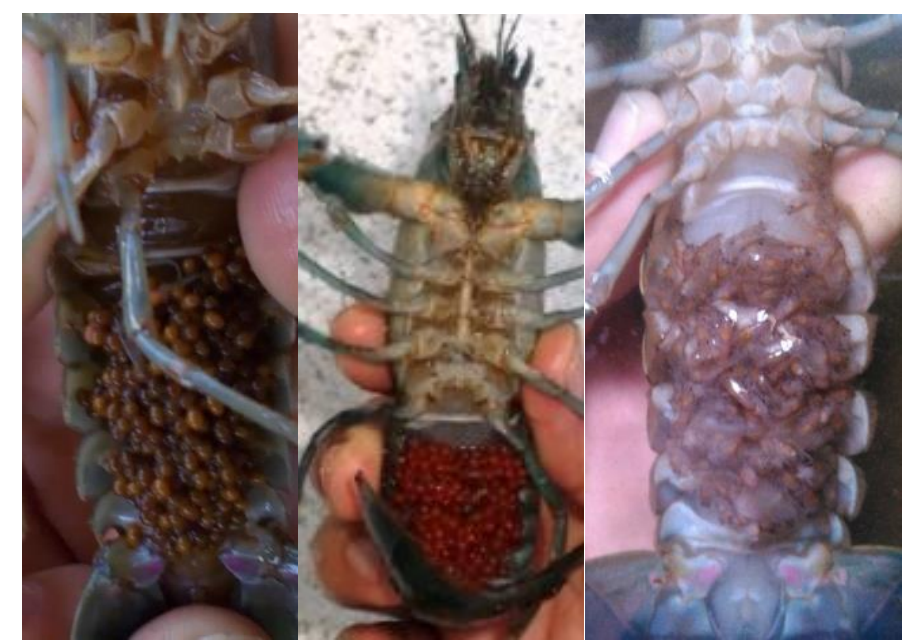

Gambar 5. Indukan lobster air tawar mengerami telur dan menggendong larva

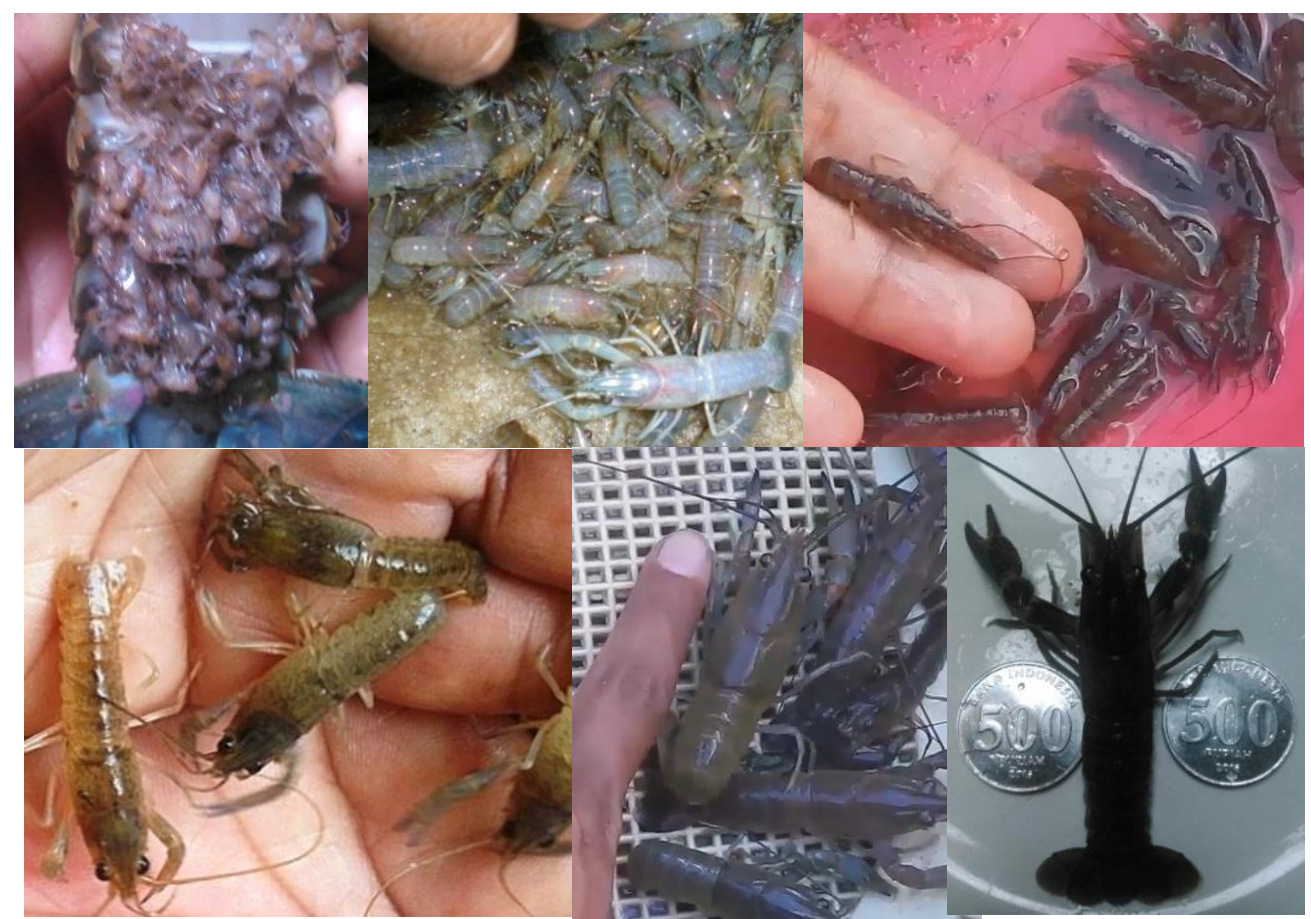

Gambar 6.Sampel benih/anakan LAT yang berhasil diproduksi mitra 


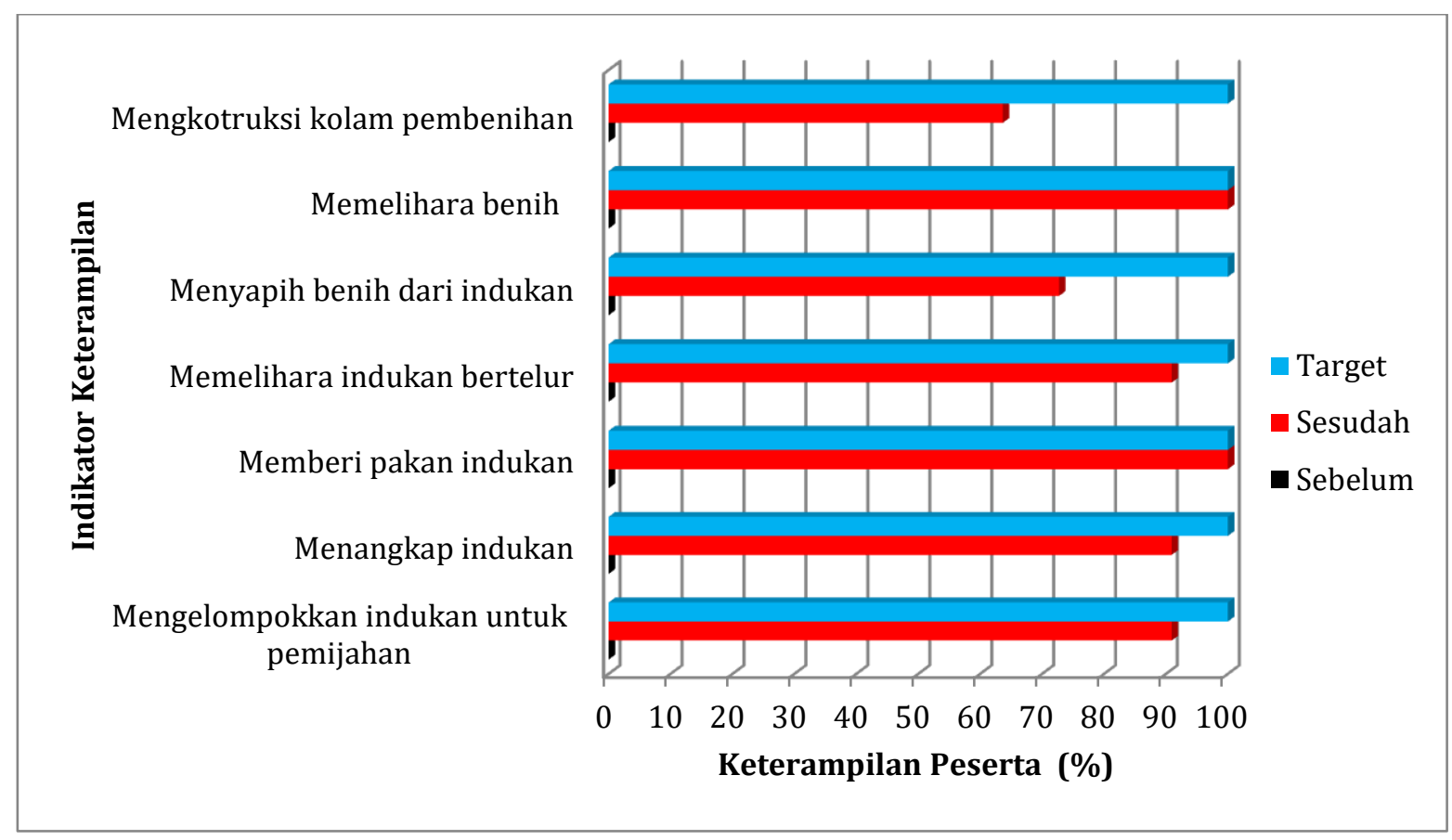

Gambar 7.Capaian keterampilan peserta dalam mengelola pembenihan lobster air tawar $(\mathrm{n}=11)$

Tabel 1. Capaian setiap kelompok pembenihkan lobster air tawar (LAT) di Kecamatan Ladongi Kabupaten Kolaka Timur

\begin{tabular}{|l|c|c|}
\hline \multicolumn{1}{|c|}{ Parameter } & Kelompok 1 & Kelompok 2 \\
\hline Pemanfaatan sarana pembenihan & $\sqrt{ }$ & $\sqrt{ }$ \\
\hline Pemijahan LAT & $\sqrt{ }$ & $\sqrt{ }$ \\
\hline Produksibenih LAT & $\sqrt{ }$ & $\sqrt{ }$ \\
\hline Menjualbenih LAT & $\sqrt{ }$ & $\sqrt{ }$ \\
\hline Kontinyuitas pasca kegiatan & $\sqrt{ }$ & $\sqrt{ }$ \\
\hline
\end{tabular}

Keterangan :

$\sqrt{ }:$ terpenuhi target

$X$ : tidak terpenuhi target

\section{Kesimpulan}

Kegiata penyuluhan, kontruksi sarana produksi, introduksi indukan yang ditindak lanjuti dengan alih teknologi dan pendampingan, berhasil dilakukan pada dua kelompok mitra. Mitra mengelola pembenihan dan memproduksi benih LAT secara mandiri. Mitra menjadi penyuplai benih LAT di Kabupaten Kolaka Timur.

\section{Ucapan Terima Kasih}

Ucapan terima kasih disampaikan kepada Direktorat Riset dan Pendabdian kepada Masyarakat Dirjen Penguatan Riset dan Pengembanga Kemenristekdikti atas dukungan dana skim Program Ipteks bagiMasyarakat (IbM) tahun 2017.

\section{Referensi}

Kudsiah, H., Rahim, S.W., Rifa'i, M.A., \& Arwan. (2018). Demplot Pengembangan Budidaya Kepiting Cangkang Lunak di Desa Salemba, Kecamatan Ujung Loi, Kabupaten Bulukumba Sulawesi Selatan. Jurnal Panrita Abdi, 2(2), 151-164. 
Parnes, P. \& Sagi, A. (2002). Intensification of redclaw crayfish Cherax quadricarinatus culture I. Hatchery and nursery system. Aquacultural Engineering 26, 251-262

Patoka, J., Wardiatno, Y., Mashar, A., Yonvitner, Wowor, D., Takdir, M., Purnamasari, L., Petrtyl, M., Kalous, L., Jerikho, R., Kouba, A \& Bláha, M. (2018). Redclaw crayfish, Cherax quadricarinatus (von Martens, 1868),widespread throughout Indonesia. BioInvasions Records, 7(2) , 185189.

Yusnaini, (2004). Laporan Budidaya Lobster Air Tawar, Lembaga Penelitian Universitas Halu oleo, Kendari.

Yusnaini, Ramli, M., \& Saenong, Z. (2017). IbM Pembenihan Lobster Air Tawar di Kabupaten Kolaka Timur. Laporan. LPPM Univ. Halu Ole, Kendari. Pp.

Yusnaini, Ramli, M., Saenong, Z., Idris, M., \& Wa Iba, (2018). Analisis Faktor Internal dan Eksternal Pengembangan Pembenihan Lobster Air Tawar (Cerax quadricarinatus) di Kabupaten Kolaka Timur. Jurnal Sains dan Inovasi Perikanan / Journal of Fishery Science and Innovation 2(1), 10-14.

Penulis:

Yusnaini, Program Studi Budidaya Perairan, Fakultas Perikanan dan Ilmu Kelautan Universitas Halu Oleo, Kendari. E-mail: yusnaini@uho.ac.id

Muhammad Ramli, Program Studi Manajemen Sumberdaya Perairan, Fakultas Perikanan dan Ilmu Kelautan Universitas Halu Oleo, Kendari. E-Mail: ramlineng@yahoo.co.id

Zainuddin Saenong,Program Manajemen, Fakultas Ekonomi dan Bisnis, Universitas Halu Oleo, Kendari. E-mail: saenongzainuddin@yahoo.com

Indriyani Nur, Program Studi Budidaya Perairan, Fakultas Perikanan dan Ilmu Kelautan Universitas Halu Oleo, Kendari. E-mail: indriyani_uho@uho.ac.id

Indrayani, Program Studi ManajemenSumberdaya Perairan,Fakultas Perikanan dan Ilmu Kelautan Universitas Halu Oleo, Kendari. E-mail: indrayani_tajudin@yahoo.com.au

Bagaimana men-sitasi artikel ini:

Yusnaini, Ramli, M., Saenong, Z., Nur, I., \& Indrayani (2020). Introduksi Indukan dan Alih Teknologi Pembenihan Lobster Air Tawar (Cerax quadicarinatus) pada Kelompok Masyarakat di Kecamatan Ladongi Kabupaten Konawe Timur. Jurnal Panrita Abdi, 4(3), 265-272 